\title{
HUBUNGAN ANTARA KEPERCAYAAN DIRI DAN KECEMASAN KOMUNIKASI INTERPERSONAL TERHADAP PERILAKU BELAJAR SISWA PADA MATA PELAJARAN FISIKA KELAS X SMAN 1 KUTAMAKMUR
}

\author{
Muliani $^{1^{*}}$, Agustia Azni ${ }^{2}$, Syarifah Rita Zahara ${ }^{1}$ \\ Dosen $^{1}$, Mahasiswa ${ }^{2}$ Program Studi Pendidikan Fisika, Universitas Malikussaleh \\ *Korespondensi: muliani@unimal.ac.id
}

\begin{abstract}
Abstrak: Tujuan penelitian ini adalah untuk mengetahui, 1). tingkat kepercayaan diri pada mata pelajaran fisika kelas X SMAN 1 Kutamakmur (variable $x_{1}$ ), 2). Tingkatkecemasan komunikasi interpersonal pada mata pelajaran fisika kelas X SMAN 1 Kutamakmur (variabel $x_{2}$ ), dan 3). hubungan antara kepercayaan diri dan kecemasan komunikasi interpersonal terhadap perilaku belajar siswa pada mata pelajaran fisika kelas X SMAN 1 Kutamakmur. Metode penelitian bersifat kuantitatif. Sampel berjumlah 31 siswa yang diambil melalui teknik random sampling. Instrumen pengumpulan data untuk kepercayaan diri, kecemasan komunikasi interpersonal dan perilaku belajar ketiganya menggunakan angket. Teknik analisis data variabel kepercayaan diri $\left(x_{1}\right)$, dan kecemasan komunikasi interpersonal $\left(x_{2}\right)$ menggunakan analisis deskriptif dan variabel perilaku belajar (Y) menggunakan inferensial yaitu regresi linear berganda dengan uji F. Berdasarkan hasil analisis data dengan menggunakan statistik deskriptif diperoleh bahwa mayoritas siswa kelas X SMAN 1 Kutamakmur memiliki kepercayaan diridalam kategori sedang dengan skor sebesar 45\%, dan mayoritas siswa kelas X SMAN1 Kutamakmur memiliki kecemasan komunikasi interpersonal dalam kategori sedang dengan skor sebesar 70\%, hasil analisis regresi linear berganda menggunakan uji $\mathrm{F}$ dapat diketahui Hasil uji hipotesis diperoleh $\mathrm{F}$ hitung $<\mathrm{F}$ table $(2,218<3,33)$, dengan nilai signifikan 0,128>0,05 maka Ho diterima, artinya Ada hubungan negatif dan signifikan antara kepercayaan diri dan kecemasan komunikasi interpersonal secara bersama-sama terhadap perilaku belajar.
\end{abstract}

Kata Kunci: Kepercayaan Diri, Kecemasan Komunikasi Interpersonal, Perilaku Belajar.

\section{THE RELATIONSHIP BETWEEN CONVIDENCE AND COMMUNICATION ANXIETY THE INTERPERSONAL BEHAVIOR OF STUDENTS ON THE PHYSICS SUBJECTS IN THE X CLASS SMAN 1 KUTAMAKMUR}

\begin{abstract}
Abtrack: The purpose of this lesearch is to know, 1). The level of confidence in the class of physics, in the class X SMAN 1 Kutamakmur (variable X1), 2). The level of interpersonal communicition anxiety on physics subjects in the X class SMAN 1 Kutamakmur (variable $\mathrm{X} 2$ ), 3). The relationship between convidence and communication anxiety the interpersonal behavior of students on the physics subjects in the X class SMAN 1 Kutamakmur. The researchb methods arc quantitative. There are 31 students taken through the random sampling tehnique. Data collection instruments for confidence, interpersonal communicatoin anxiety and learning behavior all there uses the angket. Data analysis technique $x_{1}$ dan $x_{2}$ using deducative analysis of a variable (Y) using inferential that is regression linear withthe test (F). Based on the data analysis using descriptive statistics found thatbthe students majority in the X class of SMAN 1 Kutamakmur has a modest self -confidence rating at the high of $45 \%$ and the majority of in the $\mathrm{X}$ class of SMAN 1 Kutamakmur have interpersonal communication anxiety in the medium category at a score of $70 \%$ regresion analysis results, multiple lenear used test $(\mathrm{F})$ to know the results of the hypothesis test are obtained $(\mathrm{F})$ count
\end{abstract}


$<$ F table $(2,218<3,33)$, with signivicant value $0,128>0,05$ the Ho received, meaning there is a nigative an significant connection between confidence and self-contained interpersonal communication anxiety together against learning behavior .

\section{Keyword: Confidence, Communication Anxiety Interpersonal, Educational Behavior.}

\section{PENDAHULUAN}

Pendidikan merupakan usaha yang dijalankan oleh seseorang atau sekelompok orang untuk mempengaruhi agar menjadi dewasa dan mencapai tingkat hidup dan penghidupan yang lebih tinggi (Fajriani, 2015)

Kepercayaan diri merupakan keyakinan individu akan kemampuan yang dimiliki sehingga dapat dimanfaatkan untuk mencapai kesuksesan yang dituju. Kepercayaan diri seseorang yang rendah maka komunikasi interpersonal rendah/kurang efektif, dan sebaliknya kepercayaan diri seseorang tinggi makan komunikasi interpersonal akan baik dan efektif. Hal tersebut akan menyebabkan individu mengalami kesulitan dalam mengembangkan potensi diri yang dimiliki dan menghadapi permasalahan yang akan dialami, hingga akhirnya dapat minimbulkan kecemasan dalam berinteraksi karena individu tidak yakin akan kemampuan yang dimiliki (Arif, 2004).

Komunikasi interpersonal merupakan interaksi antarindividu baik langsung atau tidak langsung, saling mempengaruhi dan tujuan yang sama untuk mengembangkan suatu hubungan (Beebe \& Mark, 2008). Pada kenyataan sekarang bahwa tidak semua individu yang memeliki kepercayaan diri yang tinggi, seperti siswa/i di SMAN 1 Kutamakmur dari kelas X-XII pernah mengalami hal tidak menyenangkan atau cemas ketika berlangsungnya pembelajaran fisika, sehingga mereka tidak tertarik untuk mengikutinya. Hal ini berimplikasi pada perubahan perilaku belajar siswa.

Banyaknya siswa menghadapi persoalan dengan mata pelajaran disebabkan mata pelajaran yang menuntut waktu dan pikiran yang banyak. Sebagian mata pelajaran yang dianggap menimbulkan masalah ialah ilmu pasti dan pengetahuan alam, seperti fisika, matematika, biologi dan kimia.

Hal ini disebabkan adanya persepsi siswa yang menganggap mata pelajaran tersebut memiliki tingkat kesulitan karena banyak istilah-istilah dan rumus- rumus yang harus dikuasai, oleh karena itu, siswa tidak berminat mempelajari mata pelajaran dimaksud, hal ini berimplikasi pada perubahan perilaku belajar yang dialami oleh siswa. Selain faktor kesulitan tersebut ada juga faktor lain yang ikut mempengaruhi perilaku belajar siswa yaitu kepercayaan diri pada siswa dan kecemasan komunikasi interpersonal.

Berdasarkan hasil wawancara dengan guru fisika di SMAN 1 kutamakmur terlihat bahwa tidak ada intensitas siswa untuk melakukan komunikasi, dan terkait dengan permasalahan kecemasan komunikasi interpersonal memperoleh bahwa ketika awal masuk sekolah di SMAN 1kutamakmur mereka menghadapi lingkungan baru dan mulai mempelajari materi fisika yang begitu banyak rumusnya dan banyak menuntuk waktu untuk memahaminya sehingga sulit untuk dipelajari.Dan ketika berlangsungnya pembelajaran, guru mengajukan pertanyaan mereka kurang percaya diri untuk menjawab dikarenakan mereka kurang memahami materi, dan takut menjawab karena cemas ditertawakan temannya jika salah tanggapan yang diajukan kepada guru. Dan hasil tanya jawab 5 siswa di SMAN 1 kutamakmur bahwa mereka mengalami hal yang tidak menyenangkan ketika masuk pelajaran fisika dan tidak berani mengeluarkan pertanyaan dan pendapatnya dketika berlangsungnya pembelajaran melainkan hanya duduk, diam, memperhatikan apa yang dijelasakan saja, dan sebagian hanya bermain- main dikelas. 
Permasalahan dalam penelitian ini adalah bagaimana tingkat kepercayaan diri siswa pada mata pelajaran fisika kelas X SMAN 1 Kutamakmur, bagaimana tingkat kecemasan komunikasi interpersonal siswa pada mata pelajaran fisika kelas X SMAN 1 Kutamakmur, apakah terdapat hubungan yang signifikan antara kepercayaan diri dan kecemasan komunikasi interpersonal terhadap perilaku belajar siswa pada mata pelajaran fisika kelas X SMAN 1 Kutamakmur.Tujuan dari permasalahn yang terjadi yaitu: untuk mengetahui tingkat kepercayaan diri siswa pada mata pelajaran fisika SMAN 1 Kutamakmur, untuk mengetahui tingka kecemasan komunikasi interpersonal siswa pada mata pelajaran fisika SMAN 1 Kutamakmur, untuk mengetahui hubungan yang signifikan antara kepercayaan diri dan kecemasan komunikasi interpersonal terhadap perilaku belajar siswa pada mata pelajaran fisika kelas X SMAN 1 Kutamakmur.

Manfaat dari penelitian ini adalah dapat mengetahui tingkat kepercayaan diri dan kecemasan komunikasi interpersonal yang dimiliki oleh siswa SMAN 1 kutamkmur. Dan solusi dari permasalahnnya yaitu meningkatkan kepercayaan diri dengan mengidentifikasi penyebab rendahnya rasa percaya diri, berpikir positif, prestasi, berani mencoba hal-hal baru.

\section{METODE}

Populasi dalam penelitian ini adalah seluruh siswa kelas X SMAN 1 kutamakmur berjumlah 45 siswa, dalam penelitian ini mengambil sampel 31 siswa dengan menggunakan rendom sampling. Metode yang digunakan yaitu pendekatan penelitian kuantitatif korelasional karena data atau informasi yang dikumpulkan diwujudkan dalam bentuk kuantitatif atau angka-angka, dan dikatakan korelasi karena penelitian ini mencari hubungan antara 3 variabel, yaitu kepercayaan diri (X1), kecemasan komunikasi interpersonal (X2) dan perilaku belajar siswa(Y). Adapun instrumen penelitian yang digunakan yaitu angket atau skala rikert. Yaitu:

1. Angket/ kuesioner merupakan alat teknik pengumpulan data yang diakukan dengan memberikan seperangkat pertanyaan atau pernyataan tertulis kepada responden untuk dijawabnya (Sugiono, 2018).

a. Kepercayaan Diri dan Kecemasan komunikasi interpersonal

Tabel 1 Interval Nilai Kepercayaan Diri dan Kecemasan Komunikasi Interpersonal

\begin{tabular}{cc}
\hline Interval Nilai & Kategori \\
\hline $15-24$ & Sangat Rendah \\
$24-33$ & Rendah \\
$33-42$ & Sedang \\
$42-51$ & Tinggi \\
$51-60$ & Sangat Tinggi \\
\hline \multicolumn{2}{c}{ Saifuddin Azwar (2013: 147-150) }
\end{tabular}

Tabel 2 Kisi- Kisi Kepercayaan Diri

\begin{tabular}{ccccccc}
\hline \multirow{2}{*}{ No } & \multirow{2}{*}{ Aspek } & Indikator & \multicolumn{2}{c}{ Jumlah soal } & \multicolumn{2}{c}{ Nomor soal } \\
\cline { 3 - 7 } & & Tidak takut diejek teman ketika & Uf & F & Uf \\
\hline \multirow{2}{*}{1} & $\begin{array}{c}\text { Memiliki rasa } \\
\text { aman }\end{array}$ & $\begin{array}{l}\text { menjawab pertanyaan dari guru } \\
\text { Mampu beradaptasi dengan materi } \\
\text { fisika dan lingkungan }\end{array}$ & 2 & 1 & 1,4 & 23
\end{tabular}


2

$$
\text { Yakin pada }
$$
kemampuan sendiri

Tidak

3 mementingkan diri sendiri dan toleran

$4 \quad$ Ambisi normal

5 Mandiri

$6 \quad$ Optimis
Menghargai kelebihan dan

kekurangan yang dimiliki

Yakin pada diri sendiri dalam mengatasi materi dalam fisika

Memahami diri sendiri dan peduli

terhadap orang lain

Dapat menerima masukan yang dari

orang lain

Melakukan tindakan sesuai dengan

kemampuan

Dapat mempertanggungjawabkan

setiap tindakan yangdilakukan

Melakukan tindakan tanpa

bergantung pada orang lain

Berusaha untuk mengerjakan tugas

tanpa bantuan orang lain

Memiliki keyakinan dalam

melakukan suatu tindakan/ tugas

yang diberikan guru

Memiliki harapan mengenai dirinya

di masa depan

Jumlah

Total: 34

$\begin{array}{cccc}2 & 1 & 2,9 & 22 \\ 1 & 1 & 7 & 24 \\ 1 & 1 & 9,11 & 21 \\ 2 & 1 & 8,10 & 26,27 \\ 2 & 1 & 12,15 & 29 \\ 1 & 2 & 7 & 28 \\ 2 & 1 & 13,16 & 30 \\ 2 & 1 & 14,18 & 32 \\ 2 & 2 & 19 & 31,33 \\ 1 & 1 & 20 & 35 \\ 20 & 15 & 20 & 15\end{array}$

Ayu lea Lailatussa' diah (2014)

Tabel 3 Kisi- Kisi Instrume Kecemasan Komunikasi Interpersonal

\begin{tabular}{|c|c|c|c|c|c|c|}
\hline \multirow{2}{*}{ No } & \multirow{2}{*}{ Aspek } & \multirow{2}{*}{ Indikator } & \multicolumn{2}{|c|}{ Jumlah soal } & \multicolumn{2}{|c|}{ Nomor soal } \\
\hline & & & $\mathrm{F}$ & Uf & $\mathrm{F}$ & Uf \\
\hline \multirow{3}{*}{1} & \multirow{2}{*}{ Unwillingness } & $\begin{array}{l}\text { kurang minat untuk } \\
\text { melakukan komunikasi }\end{array}$ & 3 & 2 & $1,3,6$ & 16 \\
\hline & & $\begin{array}{l}\text { Berusaha untuk menghindari } \\
\text { komunikasi }\end{array}$ & 3 & 2 & $7,9,12$ & $19,21,22$ \\
\hline & Unrewarding & $\begin{array}{l}\text { Tidak ada penghargaan yang } \\
\text { diberikan oleh orang lain } \\
\text { ketika berkomunikasi, } \\
\text { Kekhawatiran terhadap }\end{array}$ & 2 & 1 & 2,5 & 17 \\
\hline \multirow{2}{*}{2} & & $\begin{array}{l}\text { situasi yang dapat } \\
\text { menimbulkan kecemasan }\end{array}$ & 2 & 2 & 4,10 & 18,23 \\
\hline & Uncontrol & $\begin{array}{l}\text { Ketidakmampuan seseorang } \\
\text { dalam menghadapi situasi } \\
\text { komunikasi, }\end{array}$ & 3 & 1 & $8,11,14$ & 20,25 \\
\hline \multirow{3}{*}{3} &  & $\begin{array}{l}\text { Munculnya perasaan } \\
\text { terancam akibat adanya } \\
\text { reaksi dari orang lain }\end{array}$ & 2 & 2 & 13,15 & 24 \\
\hline & & Jumlah & 15 & 10 & 15 & 10 \\
\hline & & Total 25 & & & & \\
\hline
\end{tabular}

Tabel 4 Kisi- Kisi Instrument Perilaku Belajar 


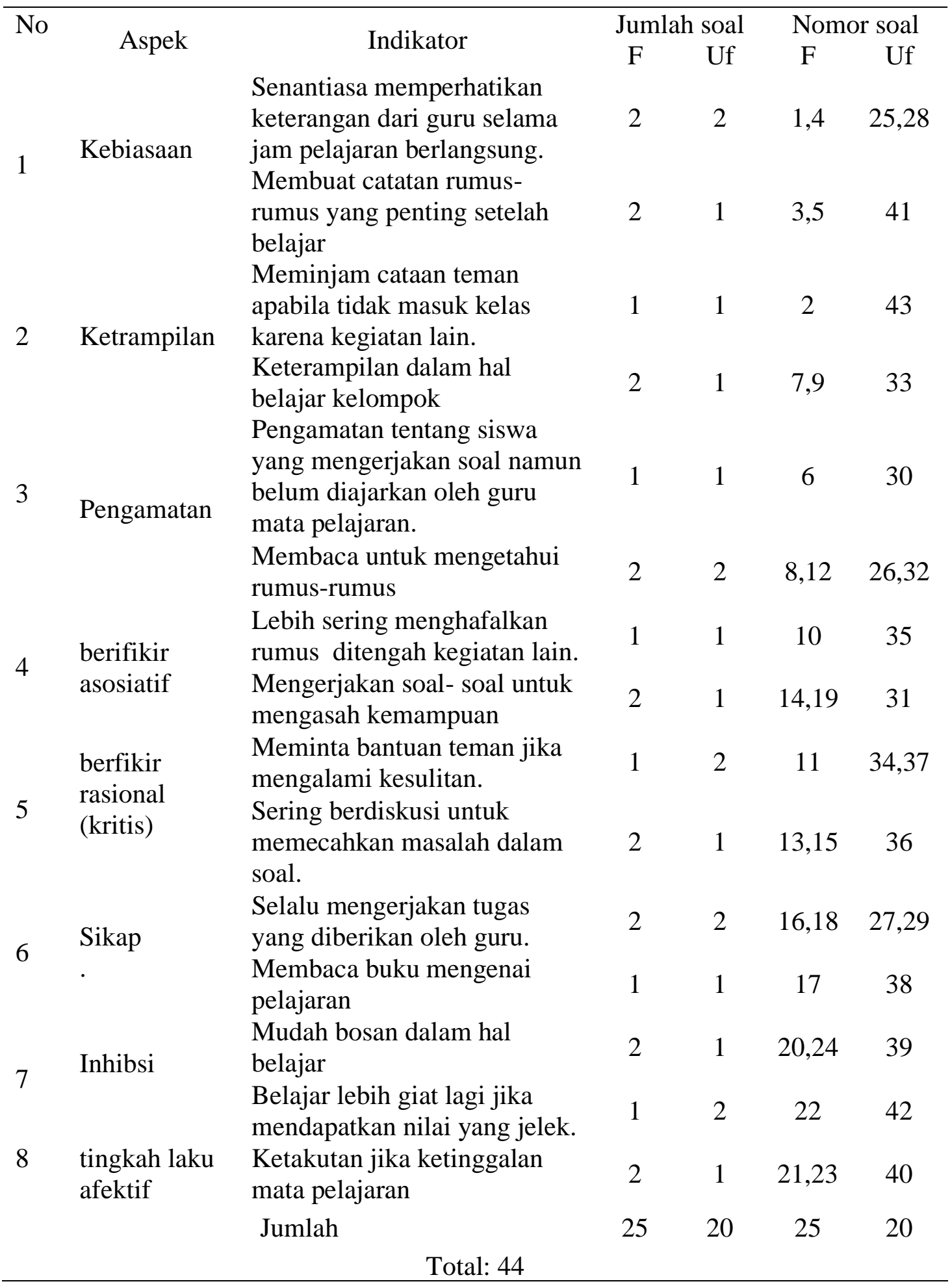

2. Dokumentasi adalah cara mengumpulkan data Pada tehnik ini, peneliti dimungkinkan memperoleh informasi dari bermacam-macam sumber tertulis atau dokumen yang ada pada responden atau tempat (Sukardi, Metodologi Penelitian Pendidikan, 2007) 


\section{HASIL DAN PEMBAHASAN}

Hasil

a. Kepercayaan Diri

Tabel 5 Deskriptif Data Kepercayaan Diri

\begin{tabular}{cccc} 
Variabel & Jumlah Item & Statistik & Skor \\
\hline \multirow{3}{*}{ Kepercayaan } & & Skor Minimum & 15 \\
Diri & \multirow{2}{*}{15} & Skor Maksimum & 60 \\
& & Mean & 37,5 \\
& & SD & 7,5 \\
\hline
\end{tabular}

Grafik Distribusi Frekuensi Kategori

Kepercayaan Diri

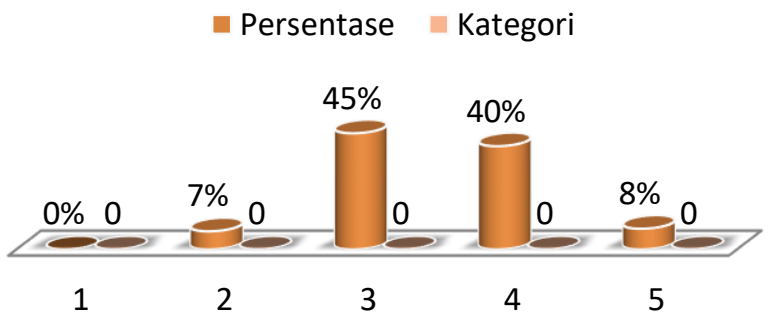

Gambar 1 Grafik Distribusi Frekuensi Kategori Kepercayaan Diri

b. Kecemasan Komunikasi Interpersonal

Tabel 6 Deskripsi Data Kecemasan Komunikasi Interpersonal

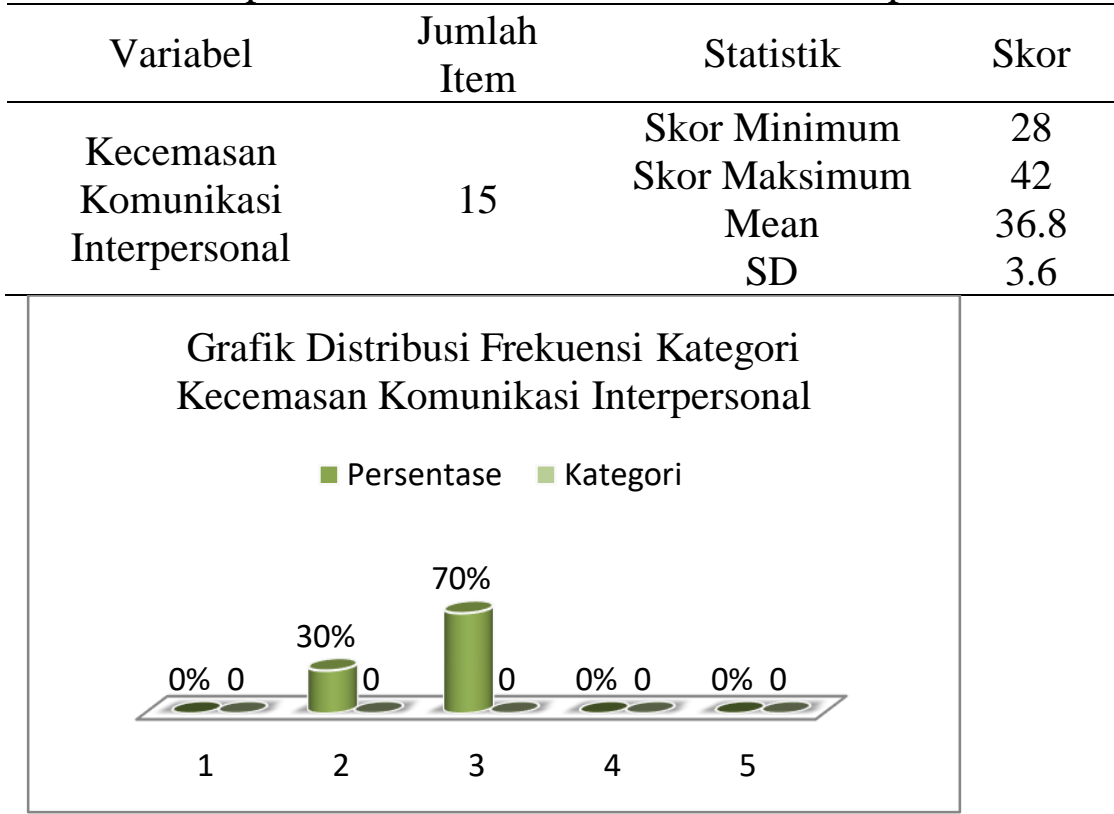

Gambar 2 Grafik Distribusi Frekuensi Kategori Kecemasan Komunikasi Interpersonal

c. Hubungan ketiga Variabel

hasil output analisis regresi dapat diketahui nilai $\mathrm{F}$ seperti pada tabel berikut ini. Uji F digunakan untuk melihat hubungan ketiga variable.

Tabel 7 Hasil Uji F

\begin{tabular}{lll}
\hline Variabel & F & Sig \\
\hline
\end{tabular}




\begin{tabular}{lrrr}
\hline Kepercayaan & diri dan & & \\
kecemasan & komunikasi & 2,218 & 0,128 \\
interpersonal & terhadap & & \\
perilaku belajar & & & \\
\hline
\end{tabular}

Karena $\mathrm{F}$ hitung $<\mathrm{F}$ tabel $(2,218<3,33)$, dengan nilai signifikan $0,128>0,05$ maka Ho diterima, artinya Ada hubungan negatif dan signifikan antara kepercayaan diri dan kecemasan komunikasi interpersonal secara bersama-sama terhadap perilaku belajar.

\section{Pembahasan}

a. Tingkat Kepercayaan Diri siswa kelas X SMAN 1 Kutamakmur

Berdasarkan hasil penelitian yang telah dilakukan, maka dapat disimpulakan bahwa sebagian besar siswa kelas X SMAN 1 Kutamakmur memiliki tingkat kepercayaan diri yang sedang. Hal ini dapat diketahui dari hasil data angket penelitian yang menunjukkan bahwa secara keseluruhan terdapat 17 siswa dengan persentase $45 \%$ berada pada kategori sedang, dan jumlah yang berada pada kategori tinggi terdapat 12 siswa dengan persentase $40 \%$, sedangkat yang berada pada kategori rendah terdapat 1 siswa dengan persentase $7 \%$, kemudian pada kategori sangat tinggi terdapat 1 siswa dengan persentase 8\%. Tingkat kepercayaan diri pada individu berbeda-beda.Perbedaan kepercayaan diri yang dimiliki oleh individu tidak muncul begitu saja. Perbedaan tersebut dapat diprediksi oleh beberapa faktor yaitu faktor internal dan faktor eksternal ((Yulan, 2013).

Tingkat kepercayaan diri siswa di SMAN 1 Kutamakmur kebanyakan siswa laki- laki yang rendah dibandingkan perempuan, terlihat dari siswa laki- laki tidak berani mengutarakan pendapat dan tidak berani bertanya akan suatu hal yang tidak dimengerti. Dan sebaliknya siswa laki- laki mengutarakan pendapat dan bertanya bukan diwaktu yang tepat melainkan mengolok- olok teman yang lain. Melainkan siswi, mereka mempergunakan kemampuaannya pada waktu dan tempat yang tepat. Berdasarkan hasil tersebut dapat disimpulkan bahwa mayoritas siswa kelas X SMAN 1 Kutamakmur memiliki tingkat kepercayaan diri dalam kategori sedang dengan skor mencapai $45 \%$.

b. Tingkat Kecemasan Komunikasi interpersonal siswa kelas X SMAN 1 Kutamakmur

Berdasarkan hasil penelitian yang telah dilakukan, terlihat bahwa sebagian besar siswa kelas X SMA Negeri 1 Kutamakmur memiliki tingkat kecemasan komunikasi interpersonal yang sedang. Hal ini dapat diketahui dari hasil data angket penelitian yang menunjukkan bahwa tidak ada siswa dalam kategori sangat tinggi dengan persentase $0 \%$, tidak ada siswa yang berkategori tinggi dengan persentase $0 \%$, terdapat 26 siswa dalam kategori sedang dengan persentase $70 \%$, dan terdapat 5 siswa yang berada pada kategori rendah dengan persentase $30 \%$, dan tidak ada siswa dalam kategori sangat rendah dengan persentase $0 \%$.

Pada penelitian ini, kecemasan komunikasi interpersonal menitikberatkan pada kecemasan yang dialami oleh individu untuk melakukan komunikasi interpersonal dengan teman, guru dan kecemasan mengenai penilaian orang lain tentang dirinya. Hal tersebut dapat dinilai melalui 3 aspek yang dikemukakan oleh Burgoon \& Ruffner (1978) dalam (Lailatussa'diyah, 2014) yaitu tidak adanya minat untuk berkomunikasi (unwillingness), tidak adanya penghargaan dalam komunikasi (unrewarding), dan rendahnya kontrol terhadap situasi komunikasi (uncontrol).

Hal yang terjadi dilapangan terlihat bahwa siswa/siswi melakukan komunikasi tidak sesuai dengan pembahasan, melainkan mereka berkomunikasi membahas hal- hal diluar 
materi. Dan ketika berkomunikasi mereka khususnya laki- laki asal lepas (tidak ada control) yang tidak berfaedah. Berdasarkan hasil tersebut terlihat bahwa tingkat Kecemasan komunikasi interpersonal pada siswa kelas X di SMAN 1 Kutamakmur termasuk pada kategori sedang dengan persentase $70 \%$.

Hal ini sejalan dengan Penelitian terdahulu yang membahas mengenai Penelitian mengenai hubungan kepercayaan diri dengan kecemasan komunikasi interpersonal telah dilakukan oleh (Diah, 2010) Subjek untuk kedua penelitian ini adalah mahasiswa UII Yogyakarta dan siswa kelas VII dan VIII di SLTPN 1 Lumbang, Pasuruan. Hasil kedua penelitian menunjukkan adanya hubungan negatif antara kepercayaan diri dengan kecemasan komunikasi interpersonal. Individu yang memiliki kepercayaan diri yang tinggi akan memiliki kecemasan komunikasi interpersonal individu tersebut rendah, sedangkan individu yang memiliki kepercayaan diri yang rendah tentu akan mempengaruhi kecemasan komunikasi interpersonalnya.

Penelitian mengenai hubungan antara kepercayaan diri dengan perilaku menyontek pada mahasiswa UST yang dilakukan oleh (Novita \& TA.Prapancha, 2015) bahwa terdapat hubungan negatif yang signifikan antara kepercayaan diri dan perilaku menyontek di Universitas Sarjanawiyata Tamansiswa. Hal ini menunjukan bahwa hipotesis yang diajukan diterima yakni semakin tinggi kepercayaan diri maka semakin rendah perilaku menyontek, semakin rendak kepercayaan diri maka semakin tinggi perilaku menyontek.

c. Hubungan kepercayaan diri dan kecemasan komunikasi interpersonal terhadap perilaku belajar siswa

Berdasarkan hasil analisis regresi linear berganda menggunakan uji $\mathrm{F}$ dapat diketahui Hasil uji hipotesis diperoleh ada hubungan negatif dan signifikan antara kepercayaan diri dan kecemasan komunikasi interpersonal terhadap perilaku belajar.Artinya, semakin tinggi kepercayaan diri dan kecemasan komunikasi interpersonal rendah maka perilaku belajar tinggi, begitu pula sebaliknya, semakin rendah kepercayaan diri dan kecemasan komunikasi interpersonal tinggi maka semakin rendah perilaku belajar siswa. Karena $\mathrm{F}$ hitung < F table $(2,218<3,33)$, dengan nilai signifikan $0,128>0,05$ makaHo diterima, artinya Ada hubungan negatif dan signifikan antara kepercayaan diri dan kecemasan komunikasi interpersonal secara bersama-sama terhadap perilaku belajar.

Perilaku belajar siswa rata- rata memiliki kepercayaan diri yang tinggi dan kecemasan komunikasi interpersonal yang rendah maka perilaku belajarnya rendah. Hal tersebut dibuktikan dengan perwujudan perilaku belajar (Syah Dr.Muhibbin, 2017) seperti: kebiasaan, keterampilan, pengamatan, berpikir asosiatif, berpikir rasional, sikap, inhibisi, dan tingkah laku afektif. Salah satu faktor yang mempengaruhi perilaku belajar adalah kecemasan komunikasi interpersonal, dan faktor yang mempengaruhi kecemasan komunikasi interpersonal salah satunya kepercayaan diri. Ketiga variabel tersebut saling berhubungan.

Penelitian mengenai hubungan antara kepercayaan diri dan kecemasan komunikasi interpersonal dengan perilaku belajar pada mata pelajaran fisika kelas x MAN 2 Model Makassar yang dilakukan oleh (Abdul Majid) bahwa terdapat hubungan yang signifikan antara kepercayaan diri dan kecemasan komunimasi interpersonal dengan perilaku belajar siswa pada mata pelajaran fisika kelas x MAN 2 model Makassar.

Perbedaan dari penelitian yang telah dilakukan yaitu sampel penelitian yang sedikit sehingga hasilnya tidak signifikan. 


\section{PENUTUP}

Berdasarkan hasil penelitian yang telah dilakukan,Maka dapat disimpulkan bahwa mayoritas kepercayaan diri siswa kelas X SMA Negeri 1 Kutamakmur termasuk dalam kategori sedang dengan skor mencapai $45 \%$. Berdasarkan hasil penelitian yang telah dilakukan, maka dapat disimpulkan bahwa mayoritas kecemasan komunikasi interpersonal siswa kelas X SMAN 1 Kutamakmur termasuk dalam kategori sedang dengan skor $70 \%$.

Berdasarkan hasil analisis regresi linear berganda menggunakan uji $\mathrm{F}$ dapat diketahui Hasil uji hipotesis diperoleh $\mathrm{F}$ hitung $<\mathrm{F}$ tabel $(2,218<3,33)$, dengan nilai signifikan $0,128>$ 0,05 maka Ho diterima, artinya Ada hubungan negatif dan signifikan antara kepercayaan diri dan kecemasan komunikasi interpersonal secara bersama-sama terhadap perilaku belajar. Artinya, kepercayaan diri dan kecemasan komunikasi interpersonal yang sedang pada penelitian ini maka ada hubungan negatif dan signifikan terhadap perilaku belajar siswa.

\section{DAFTAR PUSTAKA}

Arif, P. M. (2004). Hubungan Antara Kontrol Diri Dengan Kecemasan Komunikasi Interpersonal. Skripsi.Fakultas Psikologi-UGM.

Beebe, S., \& Mark, J. S. (2008). Interpersonal Communication Realting Others. Pearson Internation Edition.

Fajriani, A. A. (2015). Perilaku Belajar Peserta Didik Ditinjau Dari Pola Asuh Otoriter Orangtua. AULADUNA, Vol.2,No.2 :287-300.

Diah, N. (2010). Hubungan Antara Kepercayaan Diri Dengan Kecemasan Komunikasi Interpersonal pada Siswa Kelas VII \& VIII di SLTPN 1 Lumbang Pasuruan. Yogyakarta: Skripsi.Fakultas Psikologi-UIN.

Lailatussa'diyah, L. A. (2014). Hubungan Antar Kepercayaan Diri Dengan Kecemasan

Komunikasi Interpersonal Pada Siswa Kelas VII di SMP Negeri 15 Yogyakarta. Yogyakarta.

Novita, R. M., \& TA.Prapancha, H. (2015). Hubungan Antara Kepercayaan Diri Dengan Perilaku Menyontek Pada Mahasiswa UST. Jurnal SPIRITS ,6(1).

Sugiono. (2018). Metode Penelitian Kuantitatif, Kualitatif dan R\&D. Bandung: Alfabeta.

Sukardi. (2007). Metodologi Penelitian Pendidikan. Yogyakarta: PT.Bumi Aksara.

Syah Dr.Muhibbin, M. (2017). Psikologi Pendidikan Dengan pendekatan Baru. Bandung: PT.Remaja Rosdakarya.

Yulan, I. A. (2013). Peningkatan Percaya Diri Melalui Metode Journal Writing pada Siswa Kelas XI SMK N 1 Depok.Skripsi. Fakultas Ilmu Pendidikan-UNY. 